\title{
NOTA/NOTE
}

\section{Primer registro del lenguado de Herre, Aseraggodes herrei (Pleuronectiformes: Soleidae), en la isla Malpelo, Pacífico colombiano}

\section{First record of the Herre's sole, Aseraggodes herrei (Pleuronectiformes: Soleidae), at Malpelo Island, Colombian Pacific}

\author{
Melina Rodríguez-Moreno ${ }^{1,2^{*}}$ y Diego F. Lozano-Cortée ${ }^{1,3}$ \\ $\begin{array}{ll}\text { (iD) } 0000-0002-0979-0542 & \text { (iD) } 0000-0002-7046-7955\end{array}$ \\ 1. Departamento de Biología, Universidad del Valle, Cali, Colombia.melinarodmo@gmail.com \\ 2. Fundación Ecomares, Cali, Colombia. \\ 3. Red Sea Research Center, Division of Biological and Environmental Science and Engineering, King Abdullah University of Science and Technology, \\ Thuwal, Saudi Arabia.diegoflc@gmail.com \\ * Autora de correspondencia.
}

\section{RESUMEN}

A pesar de ser un género diverso con un total de 53 especies, Aseraggodes solo tiene registros confirmados de una especie en el Pacífico Oriental Tropical (POT). En esta nota se presenta el primer registro del lenguado de Herre, A. herrei, para Colombia, a partir de dos especímenes observados a $24 \mathrm{~m}$ de profundidad, en el costado oriental de la isla Malpelo. Ambos individuos estaban camuflados sobre sustrato de arena gruesa. Diferenciarlos del sustrato fue difícil, lo que podría explicar, junto con la poca disponibilidad de hábitat, por qué esta especie no había sido registrada previamente para la isla. Este registro amplía la distribución geográfica insular de A. herrei más allá de los archipiélagos de Galápagos y de Revillagigedo y de la isla del Coco en el POT. Además, resalta la importancia de las especies visualmente crípticas y estrechamente asociadas al bentos en los inventarios de riqueza íctica.

PALABRAS CLAVE: Colombia, diversidad de peces marinos, distribución geográfica, lenguado, Pacífico Oriental Tropical

\section{ABSTRACT}

$\mathrm{D}$ espite being a diverse genus with a total of 53 species worldwide, Aseraggodes has only one species record confirmed in the Tropical Eastern Pacific (TEP). In this short communication, we present the first record of the Herre's sole, A. herrei, for Colombia, from two specimens observed at a depth of $24 \mathrm{~m}$ on the east side of Malpelo Island. Both individuals were camouflaged on coarse sand substrate. Differentiating them from the bottom was difficult, which could explain, together with the low availability of habitat, why this species had not been previously recorded at Malpelo. This report broadens the insular geographic distribution of this species beyond the Galápagos and Revillagigedo archipelagos, as well as Cocos Island in the TEP, and highlights the importance of visually identifying cryptic benthic species in ichthyofaunal inventories.

KEYWORDS: Colombia, marine fish diversity, geographic distribution, flatfish, Tropical Eastern Pacific 
El lenguado de Herre (lenguado reticulado) es un pez endémico del Pacífico Oriental Tropical (POT) que se ha registrado para el archipiélago de Revillagigedos (México) y el de Galápagos (Ecuador) y para la isla del Coco (Costa Rica). En abril de 2012 se observaron dos especímenes de Aseraggodes herrei en el fondo arenoso de un arrecife de coral (El Arrecife) en la isla Malpelo mientras se hacían estudios sobre peces damisela. Los especímenes fueron fotografiados en condiciones de poca luz y junto a ellos se colocó una regla para medir su tamaño (Figura 1). Este registro amplía el rango geográfico y la distribución insular de esta especie en el POT.

Aseraggodes herrei es un pez plano que habita en aguas someras, presumiblemente hasta $75 \mathrm{~m}$. Se conoce a partir de unos pocos especímenes recolectados en lugares geográficos separados en el POT (Seale, 1940; Bussing y López, 2005; Robertson y Allen, 2015). Su descripción se llevó a cabo a partir de un ejemplar recolectado en la isla Charles (Galápagos) durante las expediciones de Allan Hancock (Seale, 1940). Esta especie se ha registrado solo en áreas marinas protegidas en el POT y no tiene valor comercial para las pesquerías (Krupp, 1995). Hasta la fecha, existen datos deficientes para evaluar el estado de sus poblaciones (Nielsen et al., 2010).

El Santuario de Flora y Fauna Malpelo $\left(4^{\circ} 0^{\prime} \mathrm{N}\right.$, $81^{\circ} 36,5^{\prime} \mathrm{W}$ ) está situado a $380 \mathrm{~km}$ hacia el occidente de la costa continental del Pacífico colombiano. La isla emerge de una montaña volcánica submarina (cresta de Malpelo) y a su alrededor predominan paredes verticales rocosas (Stead, 1975). El Arrecife es la formación coralina más grande y desarrollada de Malpelo y se encuentra en el costado oriental (Zapata y Vargas-Ángel, 2003). Hay corales entre $4 \mathrm{~m}$ y $30 \mathrm{~m}$ de profundidad y su superficie es de 2,34 ha (Chasqui y Zapata, 2007). Existe un patrón de zonificación con corales ramificados (Pocillopora capitata) que dominan la parte somera y corales masivos que dominan sustratos más profundos (Birkeland et al., 1975; Zapata y VargasÁngel, 2003). La zona profunda del arrecife tiene una franja de escombros de coral y arena hacia el sur y otra hacia el norte, lo que divide esta zona profunda en dos sectores con diferentes agregaciones coralinas (Sánchez et al., 2019).

Los dos especímenes de $A$. herrei fueron encontrados a $24 \mathrm{~m}$ en un fondo arenoso en el extremo norte de El Arrecife (Figura 1A), cerca de rocas y colonias de Gardineroseris planulata. Ambos individuos estaban camuflados con el color del fondo y su reacción a la proximidad de los buzos fue enterrarse en la arena. Un
The Herre's sole (reticulated sole) is a Tropical Eastern Pacific (TEP) endemic fish that has been reported for Revillagigedos (Mexico) and Galapagos (Ecuador) archipelagos, and Cocos island (Costa Rica). In April 2012, two specimens of Aseraggodes herrei were observed on a sandy bottom of a coral reef (El Arrecife) at Malpelo Island while undertaking surveys on damselfishes. The specimens were photographed under low light conditions and a ruler was placed next to them for scale purposes (Figure 1). This record extends its geographic range and insular occupancy in the TEP.

Aseraggodes herrei is a flatfish that inhabits shallow waters, presumably up to $75 \mathrm{~m}$. It is known from few specimens collected in separated geographic locations in the TEP (Seale, 1940; Bussing and López, 2005; Robertson and Allen, 2015). Its description was carried out based on one specimen collected in Charles Island (Galápagos) during the Allan Hancock expeditions (Seale, 1940). This species has been recorded only within marine protected areas in the TEP, and it does not have a value for fisheries (Krupp, 1995). To date, there is deficient data to evaluate its population status (Nielsen et al., 2010).

The Malpelo Flora and Fauna Sanctuary $\left(4^{\circ} 0^{\prime} \mathrm{N}\right.$, $\left.81^{\circ} 36.5^{\prime} \mathrm{W}\right)$ is located $380 \mathrm{~km}$ to the west of the mainland coast in the Colombian Pacific. The island emerges from a volcanic submarine mountain (Malpelo Ridge) and vertical rock walls predominate around it (Stead, 1975). El Arrecife is the largest and most developed coral formation at Malpelo and is located on its east coast (Zapata and Vargas-Ángel, 2003). There are corals between $4 \mathrm{~m}$ and $30 \mathrm{~m}$ depth and its area is 2.34 ha (Chasqui and Zapata, 2007). There is a zonation pattern with branching corals (Pocillopora capitata) dominating in the shallow and massive corals in deeper substrates (Birkeland et al., 1975, Zapata and Vargas-Ángel, 2003). The deep zone of the reef has a strip of coral rubble and sand to the south, and another to the north, which divides this deep zone into two sectors with different coral aggregations (Sánchez et al., 2019).

The two specimens of $A$. herrei were found at 24 $\mathrm{m}$ in a sandy bottom in the north end of El Arrecife (Figure 1A), close to boulders and colonies of Gardineroseris planulata. Both individuals were camouflaged with the color of the bottom and their reaction to divers' proximity was burying themselves into the sand. One individual was photographed complete before it escaped (Figure 1b). The digital image of the specimen was used to measure its 


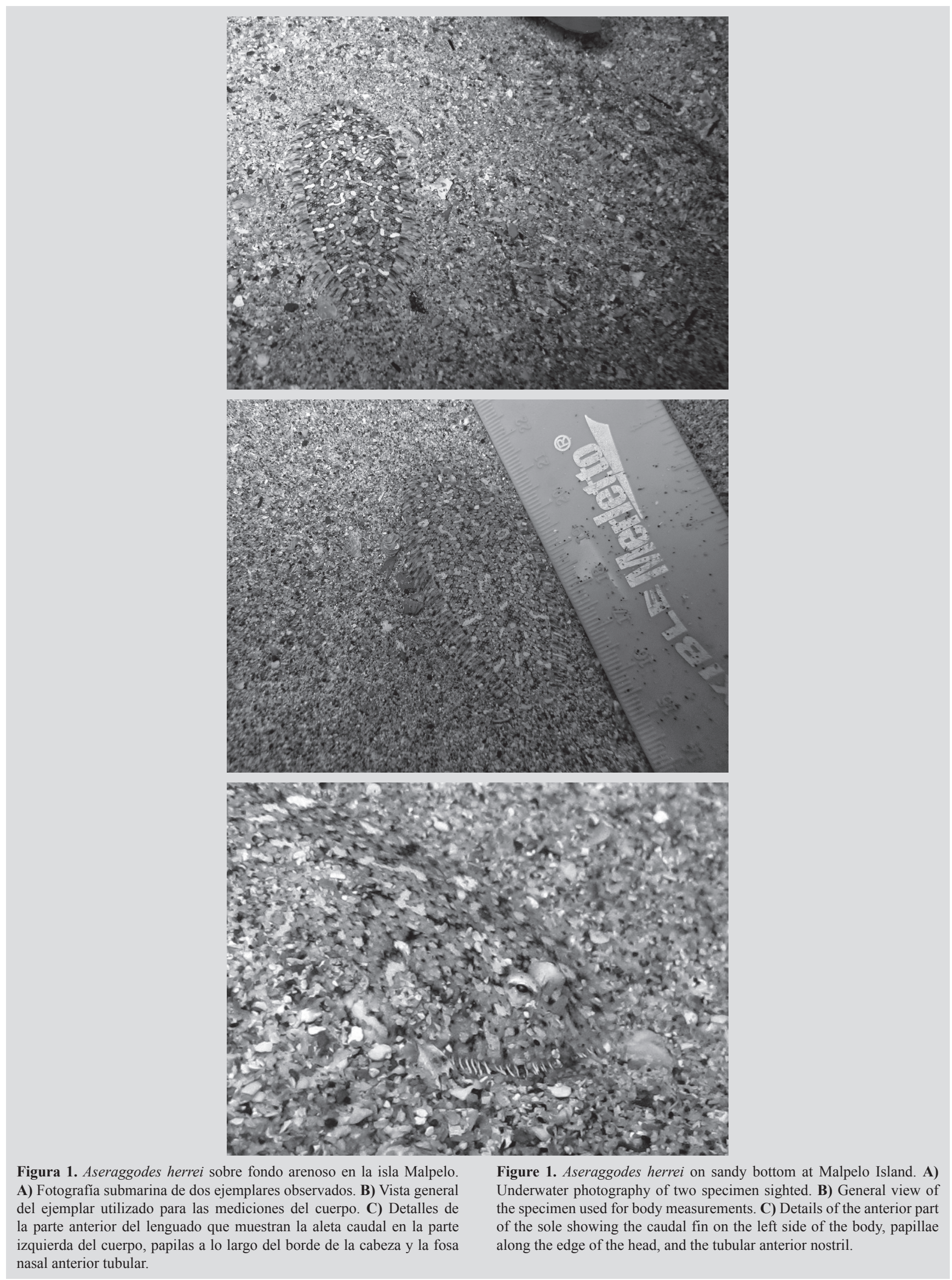


individuo fue fotografiado completo antes de que escapara (Figura 1B). La imagen digital del espécimen se utilizó para medir su longitud total (TL), su longitud estándar (SL) y la profundidad del cuerpo (BD), con ayuda del software ImageJ (Schneider et al., 2012). El espécimen tenía $\mathrm{TL}=59,9 \mathrm{~mm}, \mathrm{ST}=53,8 \mathrm{~mm}$ y $\mathrm{BD}=22,1 \mathrm{~mm}$ (Figura 1B). El patrón de color era irregular con manchas blancas, marrón claro y marrón oscuro, las cuales coincidían con el fondo arenoso. Las aletas dorsales y anales seguían un patrón de color similar y tenían algunos radios con rayas marrón oscuro y blanquecinas. La aleta caudal mostraba rayas irregulares de color marrón oscuro, marrón claro y blanco. El cuerpo tenía forma ovalada y estaba fuertemente comprimido, y la cabeza era redondeada (Figura 1A y 1B). Ambos ojos estaban en el lado derecho y los separaba un espacio estrecho. Una de las dos fosas nasales (anterior) era tubular y no excedía la altura de los ojos (Figura 1C). La línea lateral era completa y recta a lo largo del cuerpo. La aleta caudal no estaba conectada a las aletas dorsal y anal. La aleta pélvica, que se observa apuntando hacia adelante y de color blanco con dos manchas marrones en la Figura $1 \mathrm{C}$, se encontraba en el lado izquierdo de la cabeza. Esto demuestra que se trata de un pez plano del lado derecho, una característica común de la familia Soleidae. En la Figura 1C también se observa una franja característica de papilas alrededor del margen de la cabeza, visible a modo de proyecciones blancas delgadas y alargadas en la parte frontal de la cabeza. Estos caracteres visuales coincidieron con los caracteres registrados para el género (Randall et al., 2013) y la especie (Seale, 1940; Robertson y Allen, 2015), aunque no se pudieron tomar datos merísticos.

Se sabe poco sobre la biología y la ecología de $A$. herrei. Su hábitat preferido es el fondo blando, compuesto de arena y escombros de coral (Robertson et al., 2015). La disponibilidad de este hábitat en Malpelo, en aguas poco profundas, es limitada, ya que la isla está rodeada predominantemente por paredes rocosas escarpadas. Debido a su naturaleza rocosa, cantos rodados sueltos dominan las terrazas poco profundas que se encuentran en la isla (Stead, 1975; Niño et al., 2019), aunque algunos parches y franjas de arena se encuentran a unos $30 \mathrm{~m}$ de profundidad (Chasqui y Zapata, 2007; Sánchez et al., 2019). Las plataformas más profundas de Malpelo (100 a $150 \mathrm{~m}$ de profundidad) (Stead, 1975; Niño et al., 2019), donde se podrían encontrar hábitats adecuados para el lenguado de Herre y otros peces bentónicos, están inexploradas y han sido poco estudiadas. Se necesitan más investigaciones no
Total Length (TL), its Standard Length (SL) and the Body Depth (BD) with the help of ImageJ software (Schneider et al., 2012). The specimen had $\mathrm{TL}=59.9 \mathrm{~mm}, \mathrm{ST}=53.8$ $\mathrm{mm}$ and $\mathrm{BD}=22.1 \mathrm{~mm}$ (Figure 1B). The color pattern was irregular with white, light and dark brown blotches, which matched with the sandy bottom. Dorsal and anal fins followed a similar color pattern and had some dark brown and whitish striped rays. Caudal fin showed dark brown, light brown and white irregular thin stripes. The body was oval-shaped and strongly compressed, and the head was rounded (Figure 1A and 1B). Both eyes were on the right side, separated by a narrow space. One of the two nostrils (anterior) was tubular, not exceeding the eyes height (Figure 1C). The lateral line was complete and straight along the body. The caudal fin was not connected to the dorsal and anal fins. The pelvic fin, which is observed pointing forwards, white colored and with two brown blotches on Figure 1C, was on the left side of the head, showing that this is a right-sided flatfish, a common characteristic of the family Soleidae. A characteristic fringe of papillae around the margin of the head is also seen on Figure $1 \mathrm{C}$, visible as elongate thin white projections on the front of the head. These visual characters coincided with those reported for the genus (Randall et al., 2013) and the species (Seale, 1940; Robertson and Allen, 2015), although we were not able to take meristic data.

Little is known about the biology and ecology of $A$. herrei. Its preferred habitat is soft bottom, composed of sand and coral rubble (Robertson et al., 2015). The availability of this habitat on shallow waters at Malpelo is limited, as the island is predominantly surrounded by steep rocky walls. Due to their rocky nature, the few shallow terraces found at the island are dominated by loose boulders (Stead, 1975; Niño et al., 2019), although some patches and strips of sand are found around $30 \mathrm{~m}$ depth (Chasqui and Zapata, 2007; Sánchez et al., 2019). Deeper platforms at Malpelo (100 to $150 \mathrm{~m}$ depth) (Stead, 1975; Niño et al., 2019), where suitable habitats for the Herre's sole and other benthic fish could be found, are unexplored and understudied. More research is needed not only for $A$. herrei itself but also regarding the places it inhabits, especially at Malpelo, where new records have been reported on reef species, and exceptional behaviors of some species have been documented (Mora et al., 2000; Cohen-Rengifo et al., 2009; Narvaez and Zapata, 2010; Quimbayo et al., 2010; Rodríguez-Moreno et al., 2011; Rojas-Vélez and Tavera, 2017; Tavera and Rojas-Vélez, 2017). 
solo sobre $A$. herrei propiamente dicho, sino también sobre los lugares que habita, especialmente en Malpelo, lugar en el que se ha informado acerca de nuevos registros sobre especies arrecifales y se han documentado comportamientos excepcionales de algunas especies (Mora et al., 2000; Cohen-Rengifo et al., 2009; Narváez y Zapata, 2010; Quimbayo et al., 2010; Rodríguez-Moreno et al., 2011; Rojas-Vélez y Tavera, 2017; Tavera y Rojas-Vélez, 2017).

\section{AGRADECIMIENTOS}

Los autores quieren agradecer al Sistema Colombiano de Parques Nacionales Naturales y a la Fundación Malpelo por invitarlos al crucero de la expedición Seascape 2012 y proporcionarles todo el apoyo logístico para llevar a cabo la investigación submarina. También agradecen a la tripulación del buque María Patricia y a Germán Soler por ayudarles antes y durante la expedición y por mantener los ánimos de todos en alto.

\section{ACKNOWLEDGMENTS}

The authors want to thank the Colombian System of National Natural Parks and Fundación Malpelo for inviting them to the Seascape Expedition Cruise 2012 and for providing all the logistic support to undertake underwater research. Many thanks to the crew of the María Patricia vessel, and special thanks to Germán Soler for helping to the authors before and during the expedition, and keeping their spirits up.

\section{BIBLIOGRAFÍA/LITERATURE CITED}

Birkeland, C., D.L. Meyer, J.P. Stames, and C.L. Buford. 1975. Subtidal communities of Malpelo Island. Smithson. Contrib. Zool., 176: 55-68.

Bussing, W.A. y M.I. López. 2005. Peces de la isla del Coco y peces arrecifales de la costa Pacífica de América Central Meridional. Rev. Biol. Trop., 53(Suppl. 1). $192 \mathrm{p}$.

Chasqui, L. y F.A. Zapata. 2007. Tamaño y composición de dos formaciones coralinas del SFF Malpelo, Pacífico colombiano. 96-98. En: Informe del estado de los ambientes marinos y costeros en Colombia: año 2006. Ser. Publ. Per. Invemar, 8. 378 p.

Cohen-Rengifo, M., S. Bessudo, and G. Soler. 2009. Echinoderms, Malpelo Fauna and Flora Sanctuary, Colombian Pacific: new reports and distributional issues. Check List 5(3): 702-711.

Krupp, F. 1995. Soleidae. Suelas. 1614-1615. En: W. Fischer, F. Krupp, W. Schneider, C. Sommer, K. E. Carpenter y V. Niem. (Eds.). Guía FAO para la identificación de especies para los fines de la pesca. Pacifico Centro-Oriental, 3. FAO, Roma. 1813 p.

Narváez, K. and F.A. Zapata. 2010. First record and impact of the crown-of-thorns starfish, Acanthaster planci (Spinulosida: Acanthasteridae) on corals of Malpelo Island, Colombian Pacific. Rev. Biol. Trop., 58: 139-144.

Nielsen, J.G., T. Munroe, and J. Tyler. 2010. Aseraggodes herrei. The IUCN Red List of Threatened Species 2010: e.T183942A8203908. https://dx.doi. org/10.2305/IUCN.UK.2010-3.RLTS.T183942A8203908.en

Niño, D.C., C. Bermúdez-Rivas, E. Londoño-Cruz, J.R. Cantera, D.E. Valencia-Giraldo, J.F. Lázarus, L. Cabeza, L.M. Vásquez. C.P. Urbano, C.H. Grisales, J.D. Iriarte, A.L. Caicedo y A. Giraldo. 2019. Descripción física del Santuario de Fauna y Flora Malpelo. 48-77. En: Comisión Colombiana del Océano y Dirección General Marítima. (Eds.). Malpelo es Colombia: maravilla estratégica. CCO, Bogotá, D.C. 179 p.

Mora, C., J. Jiménez, and F.A. Zapata. 2000. Pontinus clemensi (Pisces: Scorpaenidae) at Malpelo island, Colombia. New specimen and geographic range extension. Bol. Invest. Mar. Cost., 29: 85-88.

Quimbayo, J.P., F.A. Zapata, S.R. Floeter, S. Bessudo, and I. Sazima. 2010. First record of cleaning by a triplefin blenny in the Tropical Pacific. Coral Reefs, 29: 909. https://doi.org/10.1007/s00338-010-0656-8

Randall, J.E., S.V. Bogorodsky, and A.O. Mal. 2013. Four new soles (Pleuronectiformes: Soleidae) of the genus Aseraggodes from the western Indian Ocean. J. Ocean Sci. Found., 8: 1-17. http://doi.org/10.5281/zenodo.1041968

Robertson, D.R. and G.R. Allen. 2015. Shorefishes of the Tropical Eastern Pacific: online information system. Version 2.0 Smithsonian Tropical Research Institute, Balboa, Panamá. 
Rodríguez-Moreno, M., M. López-Victoria, and F.A. Zapata. 2011. First record of the beaubrummel (Stegastes flavilatus) in reef habitats of Malpelo Island. Bol. Invest. Mar. Cost., 40: 181-184.

Rojas-Vélez, S. and J. Tavera. 2017. First record of the longnose puffer (Sphoeroides lobatus: Tetraodontidae) in Malpelo Island, Colombian Pacific. Bol. Invest. Mar. Cost., 46(1): 199-203. https://doi.org/10.25268/bimc.invemar.2017.46.1.723

Sánchez, J.A., A. Fuentes-Pardo, I.N. Almhain, N. Ardila-Espitia, J.R. Cantera, M. Forero-Shelton, B.S. Beltrán-León, C. Díaz, S. Bessudo, R. Navas, V. Yepes-Narváez, L. Chasqui, E. Londoño-Cruz, J.F. Lázarus, D.E. Valencia-Giraldo, F.A. Zapata, J.J. Tavera y F.O. Ladino. 2019. Diversidad de la fauna marina. 78-127. En: Comisión Colombiana del Océano y Dirección General Marítima. (Eds.). Malpelo es Colombia: maravilla estratégica. CCO, Bogotá, D.C. 179 p.

Schneider C.A., W.S. Rasband, and K.W. Eliceri. 2012. NIH Image to ImageJ: 25 years of image analysis. Nat. Met., 9: 671-675.

Seale, A. 1940. Report on fishes from Allan Hancock Expeditions in the California Academy of Sciences. Allan Hancock Pac. Exped., 9(1): 1-46.

Stead, J.A. 1975. Field observations on the Geology of Malpelo Island. Smithson. Contr. Zool., 176: 17-20.

Tavera, J. and S. Rojas-Vélez. 2017. Seeing the invisible: Chriolepis lepidota (Gobiidae), literally as never seen before. Mar. Biodivers. Rec., 10: 23. https:// doi.org/10.1186/s41200-017-0125-y

Zapata, F.A. and B. Vargas-Ángel. 2003. Corals and coral reefs of the Pacific coast of Colombia. 419-447. In: Cortés, J. (Ed.). Latin American Coral Reefs. Elsevier Science B.V., Amsterdam. 497 p.

RECIBIDO/RECEIVED: 09/08/2020

ACEPTADO/ACCEPTED: 28/09/2020 